\title{
A continued racial character of some of the Gereformeerde Kerke in South Africa: Strategic moves evading reconciliation and unity of churches in post-apartheid South Africa
}

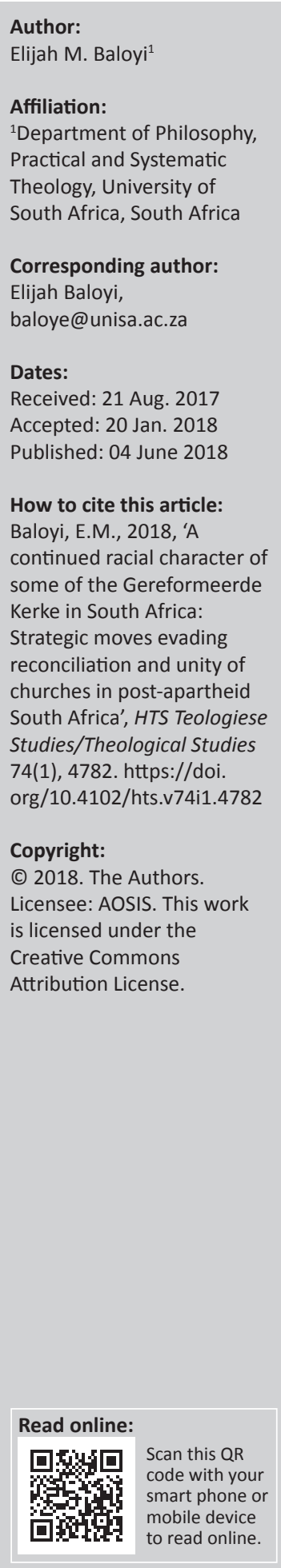

The quest for liberation of all South Africans from past racial divides since the inception of democratic government has been prioritised for more than 24 years now. Although this is an ongoing process and some achievements have been made to this end, it is yet evident that the impact of racism and apartheid still influence many lives both in and outside the churches. The Gereformeerde Kerke in South Africa (GKSA) is amongst the churches that officially removed the barriers of apartheid to have one united church. The relevant question would be to ask if relatively good progress had been made towards uniting these churches. This article intends to unveil evidence in the form of case studies that reconciliation and unity are still a journey which the members of the mentioned church should embark on. There are members of some congregations under this church who are still held within the culture of separation and hence they make it difficult to unify the church. The foundation for reconciliation had been laid down, but the challenge is now to build unity upon it. Despite some racial signs still visible in some churches, this article concerns itself in looking a place where unity, peace and reconciliation are expected to be at the top of the agenda. The article attempts to propose some strategies towards unity within the GKSA. Practical case studies will be consulted to indicate the existence of the challenge of racism in the GKSA, despite efforts to eradicate it from government and other stakeholders concerned.

\section{Introduction}

Each year 16 December, which is Reconciliation Day, brings the different views, perceptions and feelings of the people in South Africa to light. While political activists were delivering speeches at different gatherings in the name of celebrating Reconciliation, some Christians were invited to pray for unity in Soweto. It is a serious concern that we are now in the 24th year since the dawn of democracy while Soutpansberg Synod of the Reformed Churches continues to train its ministers at University of Pretoria, and the other churches of the Gereformeerde Kerke in South Africa (GKSA) continue to happily train their ministers in the North-West University. It is not important to discuss the details of the story of how they separated after working together for just about 6 years in the training of ministers, but it is concerning that there are no signs of reconciliation in the pipeline. Secondly, it is concerning that some of the ministers who are serving in the so-called multi-ethnic churches under the roofs of the Reformed churches are often treated as minors by the owners of the buildings.

One anonymous Reformed elder once said:

'Moving to the issue of culture, traditions and way of worshipping. The average member of the Gereformeerde Kerke regards the way of worshipping in multi-cultural churches as non-reformed (in the theological sense), not appropriate, noisy, unfamiliar to them, etc.' (Anonymous 2015)

Thus, language and culture are inhibiting factors for becoming one congregation (Anonymous 2015). The author is in possession of the minutes in which he quoted one white minister confronting him by saying:

Be informed that we only allow you to do mission work in the name of multi-ethnic peoples, but we have no intention that we will ever abandon our Afrikaans culture and amalgamate with you into one church. Unity is not only physical, but more spiritual. We are united in Christ even when we do not worship together. (Unknown 2016) 
This statement made the author realise that although racism had officially been abolished in South Africa, its impact is still influencing some lives, particularly within the Reformed Churches, for the sake of this study.

The role of culture and traditions, which often hides behind language, is cited as a reason for the continued disunity within some Reformed churches. The issue of starting multiethnic churches as a bridge was not a bad idea, but the question is: how long will this be kept like that when true unity is not prevailing? Although the problem at hand is focused on the Reformed churches, the article entitled 'Priest stand up to SA's racism' evidences that the entire Christian fraternity is affected by the continued racism even in 2016. In the article, Bishop William Slattery was quoted saying: 'White people were the barriers to ending racism. They are not learning to trust their brothers and sisters. This is a fact' (Nkosi 2016:6).

The fact that we are still praying for reconciliation made an me aware that although the issues of racial separations are officially abolished, the journey to reach full reconciliation and unity as South Africans is still ongoing. In other words, there is still much work to be done in order to fully achieve unity as black and white. It is apparent that the recent spate of racial practices and incidents confirms that South Africa has not yet reached a complete reconciliation after the end of apartheid and its systematic racism which lasted for many years. It is because of these incidents and practices that I have come to agree with Chikane (2015:21) that the Truth and Reconciliation Commission (TRC) headed by Archbishop Emeritus Desmond Tutu was 'at a political level, rather than at the level of ordinary people'. This indicates that people at the lower levels of society are still seated not only with the wounds caused by racism, but also with actual racism itself. Unfortunately, those who show signs of and even practice racism continue to do so because not much is being done to correct the wrongs of racial attitudes. Despite the glaring racial statements that have sparked heated debates on South African social media, it is unlikely that the church as a whole is innocent in this debacle. It is very disturbing that in the very same week in which Penny Sparrow's racial issue was trending all over social media networks, the author of this article, who is a minister of a church that holds its services under the roof of a white Afrikaans church. This is a potentially good start towards reconciliation and unity of the church.

\section{Theoretical framework and study aims}

Since the inception of democracy in South Africa there has been a growing trend from some people that reconciliation had been achieved. This pathology, which is supported by yearly celebrations held on 16 December, is for the author a point of contestation. On the contrary, Meiring (2015) contends:

We do have to face the fact that South Africa, 20 years after democracy, is still a fractured and a very divided country. Racism, alienation, xenophobia are still with us, as is the case with corruption, greed and endemic violence. (p. 22)
It is for the author a compromise to the truth, particularly for some members of the GKSA churches, to assume that unity between black and white has been achieved. It is therefore the intention of this study to use the GKSA as its case study, and in order to show that reconciliation and unity is still a possible future of the church, however, there is a responsibility for the church to play a role in the process. One of the aims of the study is to appeal to church members, both black and white, to come out and get involved in engagement and dialogue that may bring about true reconciliation and unity within the GKSA. It is the hope of the author that this study will play a role helping both the church and the country at large in the dialogue around reconciliation. Theology will regain respect amongst citizens and be kept in the conversations around reconciliation only if the church addresses the contemporary challenges facing people in their immediate context.

\section{Brief background about racism in South Africa}

The author is not trying to claim to be a scholar on Kuyper, nor he is trying to make him the focus of this study; however, as some ideas of apartheid and racism can be traced from his theology, it is imperative to make a touch on him as we discuss reconciliation in South Africa. His theology cannot be ignored as it played a significant role in confusing people to think apartheid is right. It was amongst other things his doctrine on 'Sovereignty' which he delivered in inaugurating the Vrije Universiteit in Amsterdam on 20 October 1880 which theological racists used to promote racism (Kuyper [1880] 1998:467-468). According to Patrick Baskwell (2006: 1269), Kuyper's concept of 'verzuiling' which potentially managed to pillarise Catholics, Protestsants and socialists in Netherlands directly or indirectly played a role in structuring South African apartheid and divisions. For the author, though Kuyper cannot be innocent in the game, it was mostly the readers and audience who were confused by his theology to the extent that they used it to promote apartheid and racism. This is evidenced by the fact that when he became a prime minister, Kuyper tried to introduce the so-called ethical policy, having in mind a view of human equality (Harinck 2002:187). More than 21 years into democracy, the GKSA still reduces the black church to simple noise makers who are chaotic, while they are disciplined and orderly. It is from within the wider scope of these Reformed churches that the author is going to focus on this research. There are three selected aspects, through which I argue, that are continuous signs of the unattended practices that perpetuate racism. For the sake of this article, only three selected practises will be discussed.

According to the Oxford South African School Dictionary (OUPSA 2014:490), racism is a belief that some groups (races) of people are better than others. To add to that meaning, racism is prejudice, discrimination or antagonism directed against someone of a different race based on the belief that one's own race is superior to the other. This belief of superiority usually entrenches discrimination towards the 
people believed to be of lower race or ethnicity. Even the geographical setting of the cities, towns and the like was planned according to racial lines and hence we still observe the so-called 'former white areas' in which blacks were only allowed to be seen if they were employed by whites either in their gardens or kitchens. The racial divisions of the country and that of the churches, particularly Reformed churches, affected each other in many ways; hence, Reformed theology became one of the pioneers which ensured the theological justification of racism. To prove this, the Reformed Churches (GKSA) had for many years, until 1994, been divided into different racial synods, viz., Reformed Churches in South Africa (RCSA) were initially divided during the apartheid regime into three different synods. Synod Potchefstroom (comprising the white Afrikaans-speaking population), Synod Soutpansberg (predominately Venda, and a few Tsonga-speaking congregations) and Synod Middlands (composed of different ethnic groups mainly in what is now the Gauteng province of South Africa). More than three quarters of the Synod Soutpansberg's Venda-speaking congregations are a result of the missionary endeavours of Christian Reformed Churches in Holland, while the last quarter (composed of the Shangaan people) were a result of the missionaries of the white Reformed Churches around Pretoria, which formed part of Synod Potchefstroom (Baloyi 2010:423). Synod Middlands was composed by mainly the mixed race community.

\section{The claims of the achievement of reconciliation and unity within the Gereformeerde Kerke in South Africa}

The author has decided to call the claims of the achievement of reconciliation and unity within the GKSA a school of thought, because there is not yet proof of this unity and reconciliation. In his article entitled 'National Synod of the Reformed Churches of South Africa', Le Cornu (2009) argued that black and white are united in one national synod. This claim was motivated by the events that took place in the church's 150th anniversary which took place in Potchefstroom in 2009. At that anniversary of the church, there were translating facilities available and delegates were at liberty to use their own language. The aim of this study is to argue and indicate that those events cannot prove that racism is not present in the church; hence, the study will concern itself with showing how racism is playing a role in the church. The issue with Le Cornu (2009) is that he used superficial examples to make it seem as if the reconciliation of the inequalities of the church has been overcome when it is clear that the claim of unity of the church in this regard cannot be attested to by all its members. Van Wyk (in Le Cornu 2004:2) says that 'the signs of church schism were most clearly seen when in October 2003 two different kinds of meetings were held in Pretoria'.

This kind of report is of concern as it brings to the fore the question of true unity within the church. If there is true unity within the church, then how and why did the GKSA exclude some churches under the same conditions? Secondly, is it possible for black church members who joined this synod to profess the same kind of unity that must be confessed biblically? Thirdly, can this (said) unity testify an end to racism and its roots? Lastly, are black and white churches experiencing the said unity equally? Senokoane (2015:21) contends that equality is first a natural order of God and it is aimed at uniformity in operation or effect. The issue of continued racism and racial attitudes particularly within the church shows that people of all creeds should learn to embrace love, reconciliation, peace and justice. One of the liberation theology masters, James Cone (1986), argued that theology should address contemporary people in their own circumstances and try to liberate them from any form of oppression and marginalisation. It is irresponsible for the church to leave the challenge of continued racism in South Africa in the hands of politicians alone, and it is fair for theology to not turn a blind eye against this inhuman practice. It is for this reason that the black theology of the liberation era is still relevant in dealing with the racial issues that affect South African society.

\section{The pretence of unity is confusing}

\section{Le Cornu (2009) stated that:}

The 2009 marks the first united synod by the 'white churches' and the 'black churches', following the lead of the political changes brought about by the elections of 1994. Previously, there were three black synods of whom two are now joined with the 'Afrikaner Churches and Synod'. Language problems were addressed by technology. The main language for the predominantly Afrikaner Reformed delegates is Afrikaans, a language born in and from Africa itself. Translating facilities were available with earphones and available for English, Sotho, etc. speakers from South Africa and delegates from foreign countries who could not understand the Afrikaans language. Delegates spoke in their preferred language while their words were simultaneously translated into other languages - 'One in Christ, and each in his own language'. (Ac 2:6)

Le Cornu (2009) indicated that the synods had taken a decision to become united, but not the churches on the ground level. That is why this kind of unity can be questioned. A practical example from Baloyi (2016) is that the almanac of the RCSA indicates that the so-called consulates of the Classis Limpopo (which stretches from Mokopane to Lusaka in Zambia, and is inclusive of black and white churches) are classified along racial lines. This means white pastors have been appointed as consulents of white churches, while black pastors can only be consulents of black churches. The true implication of this segregation is that white churches will be addressing their own issues, while black churches do likewise. A brief explanation of the work of the consulent is that he or she is the decision maker whenever the local church council and their pastor are faced with a difficult issue in which the pastor as a chairperson of the local church should be excused (this is similar to suspending the pastor). The interim chairperson of that meeting should be another pastor from outside the local church for the sake of the neutrality of the decision-making. This interim chairperson is called a consulent because he or she is not a full-time pastor in that 
church and is only called when there are issues that need an external chair or advice. Therefore, the implication of this is that only black pastors (consulents) will deal with the issues of black churches, while white pastors will deal with issues in their own churches.

What are the implications of having consulents operate along racial lines? Firstly, the consulent is someone who is called whenever the local church council is not in agreement with its pastor, meaning that the consulent is meant to come into the situation as a neutral mediator and even in situations when the church needs someone in an advisory role from outside their church. In brief, the consulent must step into sensitive issues which the local pastor cannot chair or resolve. Therefore, if the local black church sorts out its own problems in private and the local white church does likewise, the problems facing each local church will remain unknown within the greater community of the church which calls the unity of the GKSA as a whole into question.

\section{Afrikaans continues to be a weapon of racism (for some people)}

It should be remembered that the 1976 uprising across townships in South Africa that witnessed the killings of many black youth was sparked, amongst other things, by protests against the use of Afrikaans as a medium of instruction in schools. In South Africa, Afrikaans has been associated with black oppression. In 2016, more than 20 years into democracy, the issue of the use of Afrikaans is still contested. The Mail $\mathcal{E}$ Guardian reported that Afriforum has taken Unisa and other universities to court for deciding to stop using Afrikaans as the medium of instruction and assessment from 2017 (Mail and Guardian 2016:1). Although this is not to mean that I disregard the issue of equality of languages in South Africa, but for the sake of this study, I need to indicate that there are those who still want to see one language dominating another. In the recent violent protests against the installation of statues that commemorate people who perpetrated violent crimes against non-whites (such as Paul Kruger and Cecil Rhodes), it cannot be said that the church, particularly the Reformed Church, is innocent in the matter. This demands more intense dialogue and communication between the parties so that amicable solutions that can take the nation towards reconciliation can be found. English services in the Reformed are a good start, but more dialogue formally and informally between the two churches under one roof needs to be created.

On 27 May 2016, the author was one of the panellists invited to speak about the issue of the use of Afrikaans by a number of Reformed churches doing mission work around Pretoria and outside the country. The discussion which took place that evening was held in the Reformed Church Wapadrant and was attended by dominantly white Afrikaans-speaking churches. This was one of the positive initiatives to start from as we look for ways to unite the church across the racial lines. One of the difficult issues that arose was how Afrikaansspeaking people had failed to invite their house helpers and gardeners who have a good command of Afrikaans in the home, to accompany them to their church on Sundays. The discussion helped many of those in attendance to see how Afrikaans, which had been used to subjugate black people during apartheid, must be changed by starting to embrace one another in love. For the author, this was a positive step towards the direction of the unity and if this conversation can be continued, unity of the church will be achievable. This can be done by inviting even more other churches to play a role for this change.

The almanac by Le Cornu (2009) is written and published in Afrikaans only, meaning that those who need have the information about this synod and its churches must be able to read Afrikaans fluently. It is unappealing to imagine that this is the same synod which claims to be uniting white and black churches from South Africa to Zambia. The use of Afrikaans as the language of publication implies that churches from Zimbabwe and Zambia should not be privy to the issues contained in this almanac. The author understands this as a direct contradiction of the unity of the church. According to Van Wyk (2010:301-316), John Calvin, who is the founding father of the Reformed churches, vowed to cross 10 seas for the sake of church unity.

There are 11 official languages in South Africa according to the constitution, and Afrikaans is one of them. But there are some people who because of the dominance of Afrikaans in the GKSA abuse it to extend racial divisions that existed during apartheid (Swider 2015:1). Up till today, if one wants good recognition in the Gereformeerde Kerk, he or she should be able to express himself or herself fluently in Afrikaans. The almanac is of importance because this is a document that every Reformed Church member within the same synod is expected to purchase from the head office in Potchefstroom. There is no doubt that the information contained in the document is important for all the churches; however, it is only published in Afrikaans which can only be read and understood by the minority. The almanac contains, amongst other things, a record of all the Reformed pastors, those who have retired, those who are active and those who have passed away. The almanac also gives the updated addresses of all the churches and the contact details of all pastors. If the almanac of the church, which serves as the official source of information about the Reformed churches in Southern Africa, is still published exclusively in Afrikaans, this means that synod members who cannot understand Afrikaans cannot access the information. It should be pointed out that expenses for translations into other languages should be budgeted for in order to ensure that other non-Afrikaans speakers can benefit from the writings.

\section{The dawn and the mushrooming of multi-ethnic reformed churches in Tshwane}

Post-apartheid Tshwane has seen some traditionally white Reformed churches start to open their premises to black people in order for them to start black Reformed church 
services under their roofs. This, according to the author, is a positive step towards integrating and unifying the divided church. The primary reason that this is happening is that the white community has been slowly dying out in the city centre, while more black people seeking employment and better lives are getting into the city. This can be used as a way forward because it opens a chance of dialogue between black and white congregants. Although there may be other reasons why the black congregations are allowed into white church premises, church unity is one of the intentions because slowly integration towards separated churches would start taking place. Because of this, many are still convinced that these churches do not want a black pastor, but will tolerate the so-called 'good blacks' as pastors because they will not question the status quo. As stated initially in the Introduction, the author interviewed an Afrikaans elder in Gereformeerde Kerke, who did not want his name to be mentioned, who said:

'Moving to the issue of culture, traditions and way of worshipping. The average member of the Gereformeerde Kerke regards the way of worshipping in multi-cultural churches as non-reformed (in the theological sense), not appropriate, noisy, unfamiliar to them, etc.' (Anonymous 2015)

Thus, language and culture are inhibiting factors for becoming one congregation (Anonymous 2015). If culture is a factor then it needs to be revisited because my belief is that culture should be dynamic and open for changes, particularly where it goes wrong. It is not a good excuse after more than 20 years of democracy for some white Reformed church members to continue using traditional and cultural excuses mentioned above to delay or deny the church the unity it deserves.

Because of this divisiveness, some of the poorer churches cannot afford to invite a qualified black pastor who might be working in an academic institution such as Unisa or the University of Pretoria to serve them because of the racial divisions. They rather use the unusual methodology of having their full-time pastors being tentmakers in some of the institutions or schools, to avoid the calling fee of qualified black pastors. For me there is a need to dialogue about the possibilities of coming closer as blacks and whites trying to think of a way in which the separate black and white churches can slowly come together. In a later stage, there can be an advantage of churches making use of qualified pastors who are getting their salaries from the universities, while they only subsidise their transport allowances, for instance. This just indicates that we still have a few people who want to be bridge-builders with regard to reconciliation; meanwhile, we need more people to come as bridge-builders to reconcile the nation.

It is within the context of the multi-ethnic churches where the positive communication between white owners and black congregants can be initiated, of course under the guidance by both pastors. No one can deny that the separate services echo the sentiments that Steve Biko voiced when he said: 'Black man you are on your own'. In the GKSA multi-ethnic church, the only thing that the black congregation are offered is a shelter to worship under, and not true unity.
In his article 'Racism must stop', Araie (2015:10) confirms the continued existence of racism in South Africa by arguing that 'We have come so far, yet it seems our journey to defeat racism is far from over'. This statement indicates that although it is officially known that racism is abolished, we have a responsibility as a collective nation to work towards the change we want to see. Unity is achievable, but with all our efforts to seek it.

Fisher (2015:10) also raises the same issue when asking 'why is color still a major issue in Mzansi?' The continued subjugation and dehumanisation of black people is the one black spot that is still being fought against in South Africa. Besides other Christian denominations' role in entrenching this evil, the broader concept of the Reformed Theology has been severely criticised for supporting racism and apartheid (Byrnes 1996:1). There is no doubt that besides the owners of buildings only selecting 'good blacks' as pastors to do this mission within their premises, they also continue to dominate and decide everything for the indigenous church. Those pastors who do not submit to the paternalism by blindly listening to instructions given are told that the mission is over and that they should leave.

\section{A way forward}

The unique situation of South Africa is that both the oppressed and the oppressor are still sharing the same geographical space; this demands a unique space in which this kind of racial inequality can be addressed. It is fallacy to think that the TRC led by Archbishop Emeritus Desmond Tutu eradicated the racial inequalities of the past for ordinary citizens. The TRC might have played a role in the lives of some people, but the majority of South Africans, both black and white, are still living in their environments. This article is a point of departure for both black and white South Africans to seek ways of reconciling the nation of South Africa. One of the ways is by accepting the fact that as black and white people we should start walking together side by side, promoting a culture of mutual respect, solidarity and a culture of finding a common problem that unifies us.

The wrongness of the reading of the Bible as a way to entrench racial inequalities demands a correction of ethics, and the reading of the Bible to reverse the situation (Snyman 2008:227). Paul in Ephesians 2:11-22 addressed and overcame the issue of racial divisions by pointing at Salvation in one Jesus Christ as the cornerstone of unity. For Christians the driving force against all forms of hostility and racial barriers should be the fact that they are all saved by one Jesus, through one Spirit and to serve one God. Reconciliation is achieved by trying to give in more than one receives. Many white South Africans are not ready to engage in reconciliation and want to remain defiant in their comfort zone. From a Biblical point of view, reconciliation is achieved when both parties move out of their comfort zone and meet at a middle point. The story of Jacob and Esau's reconciliation from Genesis 32:36-43 attests to this. They did not meet in the house, but moved to a middle point and embraced each other. What the 
GKSA can learn from the story of Jacob and Esau is the following:

1. Power of faith - Jacob had enough faith to decide to go back and reunite with his brother after many years of separation. It was the same faith that saw Jacob wrestling with an angel that saw him seeking a blessing to meet with his brother. You always need the blessing of God when initiating talks or debates about reconciliation. This is not about being too holy or too spiritual, but there is a tendency amongst Christians to preach what they do not live. You cannot preach that 'Nothing is impossible with God' while you do not trust that God can help you through challenges of this nature. Although the South African churches met to pray for issues such as the rain during the 2016 draught, reconciliation needs the same type of faith when engaging with it. The argument of advancing faith in the Jacob-Esau encounter received much support from Wolicki (2015:1) in his blog entitled 'How a Jacob and Esau encounter is the secret to advancing faith'.

2. Sacrifice - Jacob sacrificed many of his belongings for the reconciliation to happen. He sent gifts to his wronged brother. Although the Midrash raises many questions around the meaning of Jacob and Esau's kiss outside the home, in my understanding this was not a kiss under the pretence of revenge. Coming to know the truth, acknowledging the wrongs of the past and a readiness to move into a different direction is the transformation that needs to take place between black and white brothers and sisters in South Africa.

3. Reconciliation took place in the middle, and not in Jacob's or Esau's house. According to Feldman (1956:482), the weeping of Jacob and Esau during the kiss, even though Rabi of England Dr JH Hertz (1938:125) thought of the presence of the hatred feelings during the kiss, indicates that this was a reconciliation that came after a long time of separation and bitterness. Moving out of our comfort zone is what is needed from both black and white parties in South Africa. Heller (1998:1) says: 'At last the moment of truth arrives. Esau makes the first overture: He embraces Jacob, falls on his neck, and kisses him. The tension had been broken'. Reconciliation comes after the breaking of the tension. It is also called the moment of truth; hence, the TRC in South Africa made its own relevance. According to Weiss (1998:1), reconciliation takes place alongside forgiveness which encompasses understanding, compassion and committing oneself to not repeat a wrongdoing of the past.

After Jesus taught and accommodated even the Samaritans who were trying to be enemies with Jews, Paul came in and emphasised this point in Galatians 3:28 when he said: 'There is neither an Jew or gentile, neither slave nor free, nor is there male and female, for you are all one in Christ Jesus'.

In Heller's (1998) article 'The healing of the open wound', when Jacob and Esau met after 20 years of separation, the meeting was like that of the warriors, Esau surrounding himself with a 400-man army. According to Heller (1998:1), the tension was only broken after Esau made the first overture and embraced Jacob and kissed him. In the Midrash there are many questions around the meaning of this kiss; however, we know that this was not only a lip kiss under the pretence of revenge. Coming to know the truth, acknowledging the wrongs of the past and a readiness to move in a different direction is the transformation that took place in the hearts of the two brothers. That is where the role of the Truth and Reconciliation Commission headed by Desmond Tutu tried to make its relevance and it said:

However, how painful the experience has been, we remain convinced that there cannot be healing without the truth. Not only the pain and injustice of thousands needed to be uncovered. The fatal ideology behind it, the structure erected to support apartheid needed to be scrutinized. (TRC 1998:4)

The present attitude of some white Afrikaners in trying to protect their supremacy, land and wealth by evading the talks about racism and reconciliation is not going to help the country move towards unity. Although the issue of forgiveness between Jacob and Esau had nothing to do with racism, their willingness to resolve and reunite after years of separation can be used as an example when we seek ways to unite previously divided South Africans. Parsitau (2015) asserts that:

Forgiveness includes some forms of communal soul searching in the long term to cultivate goodwill and secure the future. Genuine forgiveness should confront the stark reality of forgiving mutual affirmation and co-existence with former enemies. (p. 76)

That is why Meiring (2015:22) asserts that as reconciliation does not come easy, there are a number of prerequisites for the process of forgiveness and healing. Black and white Reformed churches should be ready to find a common uniting cause as they go through forgiveness as a way towards reconciliation and unity.

In his book 'Building peace', Lederach (1998:29) discusses good options on how to reconcile a fragmented society. He argues that reconciliation is a place where people and things come together. Discussing the important means of bringing peace, Lederach (1998:37) uses a picture of a pyramid in which the church needs to identify the highly respected, influential and leading figures to be incorporated into the strategy of peace. This is very much in line with Tshaka's (2013:192) view that ministers and pastors are expected to occupy dual roles as spiritual and secular leaders in our communities. Baloyi (2015:6) emphasises this by arguing that the church is, amongst other responsibilities, a custodian of peace in the world. The GKSA can provide a forum where not only ministers, but also ordinary members of the church from both sides talk and a workshop where congregants are openly encouraged to talk about every racial issue. A possibility for the GKSA would be to ask for facilitators to come and facilitate these workshops, seminars or conferences. The synod also needs to advocate for the 
agencies of unity in different churches, not by way of prescribing but by advising the churches to promote unity and justice on a congregational level. Lederach argues that a fragmented society needs strategic commitments towards the approaches that are likely to have the most enduring positive impact in building relationships and peace (1997:93). Amongst other things, the rebalancing of power, confrontational negotiations, conscientisation and conflict resolution approaches will help defuse immediate face-toface tensions. These sentiments are echoed by Parsitau who articulated that it is necessary to commit to building just and peaceful realities and relationships (Parsitau 2015:63). Hope for a united future can be found in Khumalo (2015:10), when he stated in his report that the meeting of former South African Defence Force soldiers and pastors such as Reverend Frank Chikane held at Khotso House was targeted at making reconciliation in South Africa a reality. For the author it would have made a difference if follow-ups were continued from the 1988 National Initiative for leaders and academics, amongst whom Frank Chikane, David Bosch, Michael Cassidy, Denise Ackerman are a few. Bongani Goba and others were reflecting on the issue of reconciliation in Pietermaritzburg.

For those who have multi-ethnic churches, if the objective of the mission is to reach unity, having separate services and separate pastors just delays the vision of unity. Dreaming of a united church is not enough, but it is the time to try and move out of our comfort zones by initiating practices such as pulpit exchange between the black and white churches. Just as there is the saying 'justice delayed is justice denied', unity delayed is unity denied. It is time that the white churches that are about to close because of the loss of membership start inviting available black pastors to minister to an inclusive church instead of segregating the pastors and having them evangelise to black people exclusively. This action must not be misunderstood as trying to destroy the Afrikaans language and culture, but as a means of trying to bring divided people closer. There still is a need for white Christian brothers in Christ to prove themselves as brothers to black Christian brothers (Biko 2015:63). Opoku (1988:242) notes that the church has no right to turn people into strangers in their own land.

Mancotywa (2016:11) is correct in arguing that since the inception of democracy and the abolishment of apartheid, only the symptoms of racism have been addressed, but the core causes of racism have not yet been dealt with. The biblical story of Lazarus and the rich man is remembered quickly where the rich man expected to continue to have Lazarus as his servant after death even though he did not try to change the poor condition of Lazarus' life (Lk 16:24, 27). From these two verses, we can see that the attitude of the rich man is still that of someone who is used to sending his servants. The manner in which the rich man insists that Lazarus should be sent to him and to his brothers speaks of the issue of oppression in South Africa. The author supports the idea of trying to avoid practices that potentially promote racism and embrace practices that promote unity of the church. But he does not agree with the suggestion by the African National Congress chief whip Sizani Stone that the German Holocaust model should be used to deal with the current trend of racism in South Africa (Malefane2016:4). The holocaust has its own discussion which is not intended for this article.

Reconciliation is undoubtedly an expensive project; hence, I am in agreement with Els (2007) on the fact that it demands obedience. One of the retired professors of the GKSA responded to Cornelius by saying:

Apartheid became so much part of the system of people and
caused so much blinding of people, that it is difficult to say
whether it was a climate of accepting, a climate of expectation, a
new openness to the future. Reconciliation is not something that
you can establish overnight. Reconciliation is a growth process
and a person's eyes must open to see from Scripture that
reconciliation is basically to do with the relationship between
God and man in Christ and that this has consequences for society.
(p. 157)

When Jesus Christ said Christians need to be the salt and light of the world (Mt 5:13-14), he was giving an instruction that calls Christians to be life changers in their immediate situations, including involvement in reconciling a racially divided South Africa.

The author supports the correctness of Villa-VaVincecio and De Gruchy (1985:128) when they advocated that the journey towards reconciliation and forgiveness is the quest for truth and there cannot be a genuine reconciliation without truth. It is lastly very important to note that within the Christian fraternity, it is firstly the reconciliation with God that can enable people to understand the reconciliation with one another. I am with Meiring (2015:23) that all Christians need to recognise and accept their own responsibility to be ambassadors of reconciliation in this country.

\section{Conclusion}

The issue of integration between the previously divided races demands that though the Reformed churches have already initiated something positive in the form of multiethnic services, more dialogue must take place as to how to move from these separate services to one united church. Because there is a push to end racism, the churches must be assisted from the synod downwards to start dialogues and engagements towards complete unity because it will be help to continue with separate services for ever. It is advisable that as the church seeks to unify itself, the teachings of Jesus across races as well as that of Paul when saying: 'There is neither a Jew nor Greek, there is neither slave nor free, nor is there male and female'. The church is called into unity and that means it is responsible for removing all barriers to unity. To be more precise, the value of mutual respect, brotherly love as well as equality needs to be cultivated in the religious context, particularly in the churches. 


\section{Acknowledgements Competing interests}

The author declares that he or she has no financial or personal relationships which may have inappropriately influenced him or her in writing this article.

\section{References}

African News Agency, 2016, 'AfriForum takes Unisa to court over language policy', Mail and Guardian, 25 July, viewed 15 March 2018, from https://mg.co.za Anonymous, 2015, An email in possession of the author, viewed January 2016.

Araie, F., 2015, 'Racism must be stopped', Daily Sun, 07 December, p. 10.

Baloyi, M.E., 2010, 'The sustentasie problem in the reformed churches of South Africa: Unmasking the dilemma facing black theologians', Scriptura 105, 421-433. https://doi.org/10.7833/105-0-154

Baloyi, M.E., 2015, 'The Christian church's role in the escalating mob justice system in our black townships - An African pastoral view', HTS Teologiese Studies/Theological Studies 71(2), Art. \#2833, 1-7. https://doi.org/10.4102/hts.v71i2.2833

Baloyi, M.E., 2016, 'Unpacking the downside of sustentasie on African theology and theologians: A need for contextual black theology as a liberative ingredient for the black Reformed Churches', HTS Teologiese Studies/Theological Studies 72(1), a3161. https://doi.org/10.4102/hts.v72i1.3161

Baskwell, P., 2006, 'Kuyper and Apartheid: A revisiting', HTS 62(4), 1269-1290.

Biko, S., 2015, I write what I like: Selected writings, University of Chicago Press, Chicago, IL.

Byrnes, R.M. (ed.), 1996, South Africa: A country study, GPO for the Library of Congress, Washington, DC.

Chikane, F., 2015, 'A prayer for a divided SA to heal the wounds of the past', Sunday Times, 13 December, p. 21.

Cone, J.H., 1986, A Black theology of liberation, Orbis Books, New York.

Els, C.W., 2007, 'Reconciliation in Southern Africa: The role of the Afrikaans churches', $\mathrm{PhD}$ thesis, University of Pretoria.

Feldman, S.S., 1956, 'Crying at the happy ending', Journal of the American Psychoanalytic Association 4(3), 447-485.

Fisher, N., 2015, 'Let's stop playing the race card', The Daily Sun, 07 December, p. 10.

Harinck, G., 2002, 'Abraham Kuyper, South Africa and Apartheid', The Princeton Seminary Bulletin XXIII(2), 184-187 (New Series 2002).

Heller, L., 1998, The meeting of Jacob and Esau: The healing of the open wound, viewed 15 March 2018, from http://www.reformjudaism.org

Hertz, J.H., 1938, The Pentatteuch. Hebrew text, English translation and commentary, Soncino Press, London.

Khumalo, J., 2015, 'Reconciliation on the table', The Daily Sun, 10 December, p. 6.

Kuyper, A., (1880) 1998, Souvereiniteit in eigen kring, Amsterdam, Kruyt.
Le Cornu, S., 2004, 'Die Dordtse Leerreëls vir ons tyd', Die Kerkblad 107(3167), 24.

Le Cornu. S., 2009, Gereformeerde Kerke In Suid-Afrika Handelinge Van Die Eerste Algemene Sinode Van Die Gereformeerde Kerke In Suid-Afrika Gehou Te Potchefstroom Op 5 Januarie 2009 En Volgende Dae Asook 29 Junie 2009 En Volgende Dae, viewed 15 March 2018, from http://gksa.org.za/pdf/sinode\%20 argief/handelingefinaal.pdf

Lederach, J.P., 1998, Building peace. Sustainable reconciliation in divided societies, United States Institutes of Peace Press, Washington, DC.

Malefane, M., 2016, 'ANC not to hold back on racists- Sizani', The Sowetan, 13 January, p. 4.

Mancotywa, S., 2016, 'Celebrating our shared heritage key to harmony', The Sowetan, 12 January.

Meiring, P.J.G., 2015, Boenhoeffer and costly reconciliation in South Africa- through the lens of South African Truth and Reconciliation Commission.

Nkosi, B., 2016, 'Priests stand up to SA's racism', The Sowetan, viewed 02 September 2016, from www.pressreader.com

Opoku, K.A., 1988, 'The church in Africa and contemporary sociological challenges', TheEcumenicalReview40(2),241-255.https://doi.org/10.1111/j.1758-6623.1988. tb01537.x

OUPSA, 2014, Oxford South African School dictionary, 3rd edn.

Parsitau, D.S., 2014, Embodying Holiness: Gender, Sex, Bodies and Patriarcha Imaginaries in Neo-Pentecostal Church in Kenya, in Augustine Agwuele (2014), Imaginaries in Neo-Pentecostal Church in Kenya, in Augustine Agwuele (2014),
Body talk and cultural identity in the African world. Equinox Publishers, TX, viewed Body talk and cultural identity in the
n.d., from www.equinoxpub.com

Senokoane, B.B., 2015, Revolution: The means to liberation and reconciliation, in F.H. Chimhanda, V.M.S. Moloni \& I.D. Mothoagae (eds.), African theological reflections: Critical voices on liberation, leadership, gender and eco-justice, Research Institute for Theology and Religion, University of South Africa.

Snyman, G., 2008, 'David and Shimei: Innocent victim and perpetrator?', Old Testament Essays 21(2), 435-454.

Swider, A., 2015, Things you didn't know about Post-Apartheid Afrikaans culture, viewed 01 December 2015, from http://afkinsider.com/79083/10-things-didntknow-afrikaans-culture-post-apartheid/

Truth and Reconciliation Commission of South Africa (TRC), 1998, Report, vol. 4, Juta, Cape Town, viewed 06 January 2017, from http://www.justice.gov.za/trc/report/ finalreport/volume $\% 204$,pdf

Tshaka, R.S., 2013, Do our theological methodologies help us to deal with situations of violence in black communities, specifically afrophobia? So ganz anders. Fremdheit als theologisches und gesellschaftliches Phänomen, Marburg, GBFE, Francke.

Unknown, 2016, A conversation with a white pastoral delegation from the reformed church, Notes in possession of the researcher, Unpublished church meeting.

Van Wyk, J.H., 2010, 'To cross ten seas: Calvin on the unity of the church- a contribution to a more responsible ecclesiology', In die skriflig 44(2), 301-316. https://doi. org/10.4102/ids.v44i2.148

Villa-Vicencio, C. \& De Gruchy, J.W. (eds.), 1985, Resistance and hope, South African essays in honour of Beyers Naude, Eerdmans, Grand Rapids, MI.

Weiss, D.A., 1998, Repairing past wrongs or smoothing out the rough edges, viewed 15 March 2018, from http://www.reformjudaism.org

Wolicki, P., 2015, 'How Jacob and Esau encounter is the secret to advancing faith', Charisma News, 15 December, viewed 11 January 2018, from www. charismanews.com 